\title{
Self-Respect or Self-Delusion? Tomasi and Rawls on the Basic Liberties
}

\author{
Richard Penny ${ }^{1}$
}

Published online: 26 November 2015

(C) The Author(s) 2015. This article is published with open access at Springerlink.com

\begin{abstract}
A central feature of John Tomasi's 'Free Market Fairness' is the emphasis it places upon the good of self-respect. Like Rawls, Tomasi believes that accounts of justice ought to offer support for the self-respect of citizens. Indeed, this is a key way in which Tomasi aspires to engage with the 'high-liberal' tradition. Unlike Rawls however, Tomasi argues that this support is best provided by our treating a broader set of economic liberties as basic liberties. In this paper I raise two concerns about this latter claim. Firstly, I trace a number of significant ways in which Tomasi's discussion of self-respect differs from that of Rawls. Whilst such divergences are not necessarily problematic, I argue that they serve to limit the purchase his account has on left-liberals. Further, I argue that the ideal of selfrespect is more deeply 'hard-wired' into Rawls's account of justice than Tomasi recognises. As such, Tomasi fails to address the full range of additional (and important) ways in which Rawls expects his principles of justice to support citizens' self-respect. I argue that this also limits the force of Tomasi's claims. Secondly, and more seriously, I argue that there are significant tensions between Tomasi's discussion of self-respect and his most forceful argument (the 'greater wealth thesis') in favour of the market democratic model he proposes. I argue firstly that Tomasi's account of when (and why) citizens' self-respect is jeopardised does not allow us to readily distinguish between economic security born of systems of welfare and redistribution, and economic security born of market forces and historical contingency. And more troubling still, is Tomasi's belief that self-respecting citizens must view themselves as a 'central cause' of their situation. Such self-conceptions, I argue, can only coexist alongside the greater wealth thesis if citizens engage in quite naked self-delusions about their causal power. I argue that theorists of justice have good reason to be suspicious of promulgating such delusions and, as such, that this
\end{abstract}

Richard Penny

rich.penny@southampton.ac.uk

1 Department of Politics, University of Southampton, Southampton, UK 
poses a serious problem for a justification of market democracy which aspires to rest upon an appeal to self-respect.

Keywords Rawls · Tomasi - Self-respect · Market democracy · Justice

At the heart of Free Market Fairness (Tomasi 2012; hereafter FMF) lies a delicate balancing act. John Tomasi wants to offer a market-flavoured account of deliberative justice which is, on the one hand, genuinely distinct, but on the other, amenable to interpretation within the broadly Rawlsian tradition that Tomasi sees as dominant. As such, Tomasi's favoured account ('market democracy') has the unenviable task of marrying libertarian ideals of robust property rights ('economic liberties') and the ideal of society as a spontaneous order, with the 'high-liberal' claims that we should assess the 'social justice' of institutions as a whole, and justify our principles of justice in a public and deliberative manner. I am not persuaded that such a marriage is in the interests of either party, but Tomasi's attempt to reconcile both is elegant and engaging.

One of the most important ways in which Tomasi seeks to engage within the Rawlsian or left-liberal tradition is with his focus on the good of self-respect. Tomasi, like Rawls, believes that accounts of justice ought to offer the prospect of support for the self-respect of the citizens they address (Tomasi 2012, pp. 93-95). Unlike Rawls however, Tomasi argues that citizens' self-respect is best secured, not by the wider state involvement in economic affairs that accompanies Rawls's favoured model of a 'property-owning democracy', but rather by treating a broader set of economic liberties as basic liberties (Tomasi 2012, p. 76). These basic economic liberties, on Tomasi's account, would carve out a wider space in which individuals might develop and exercise their capacities as responsible self-authorsa process which risks being stunted by the more interventionist model that Rawls proposes (Tomasi 2012, pp. 80-84).

In this paper I will raise a number of concerns about Tomasi's account of selfrespect, and the work he expects it to do in his account of market democracy. I begin by focusing critically on the account of self-respect that Tomasi offers as a basis for his criticism of the left-liberal position. In the first section I draw attention to some important differences between the ideas of self-respect utilised by Rawls and Tomasi. These differences, I argue, serve to deepen the justification Rawlsians can give for their account of the basic liberties, and to limit the force of the claims Tomasi presses against them. In section two I move to consider Tomasi's claim that the exclusion of thick economic liberties from the basic liberties is incompatible with the development of citizens' self-respect and self-authorship. I reject this claim on the grounds that Tomasi fails to attend to the degree to which restrictions on economic liberties are 'baked into' the model of deliberative community he presupposes, and may equally be thought to increase some citizens' capacity for self-authorship. In the third section I assess the links Tomasi draws between one's self-respect and one's being a 'central cause' of one's situation. I argue that Tomasi greatly exaggerates the agent-centred element of self-respect, such that his account is neither desirable, nor (in my view) plausible. 
In the fourth section I broaden the scope of my argument to address the way Tomasi expects his accounts of self-respect and self-authorship to function within the 'market democratic' model he advocates. I argue that there is a fatal tension between the key positive claim Tomasi makes for market democracy-the 'greater wealth thesis' - and the reasons of self-authorship he martials against the Rawlsian account of the basic liberties. In short, Tomasi's account of the greater wealth thesis, and his account of self-authorship can be only be rendered compatible through a process of quite naked self-delusion on the part of citizens. This, I claim, gives us reasons to doubt the very foundations of the market democratic project.

\section{Rawls on Self-Respect}

Rawls saw the development and maintenance of citizens' self-respect as a fundamental question that accounts of justice must grapple with (Rawls 1999, p. 386). I do not think it is an exaggeration to say that self-respect plays a similarly important role in Tomasi's defence of market democracy. Thus whilst Tomasi's discussion of self-respect is considerably (and thankfully) more straightforward than that of Rawls, the role he affords to self-respect at what I take to be some of the most critical junctures of FMF is significant nonetheless.

In particular, self-respect acts as an important 'Trojan-horse' by which Tomasi is able to smuggle the wider economic liberties that he favours into the more restricted class of basic liberties which Rawls is concerned with. In order to perform this manoeuvre, Tomasi asks us to consider Rawls's defence of a narrower class of basic liberties-which eschews the kinds of strong freedom of contract and rights to productive property that Tomasi favours (Tomasi 2012, pp. 264-266). Rawls's justification here appears to turn on whether or not various kinds of economic rights support our development of 'a sense of personal independence and self-respect, both of which are essential for the development and exercise of the two moral powers' (Rawls 1993, p. 298). This is to say that only those rights and liberties which support our sense of self-respect or self-authorship ${ }^{1}$ in this way appear to be candidates for being treated as basic liberties. It is for this reason that Rawls is happy to accept that a restricted right to own (non-productive) property might be understood as a basic liberty, given that he expects this kind of property to act as an important basis of self-respect (Rawls 2001, p. 114).

Tomasi's response is to accept the standard that Rawls proposes-that basic liberties ought to be identified by their role in supporting citizens' development of their sense of self-respect or self-authorship_-but to question whether Rawls applies this standard fairly. Tomasi's key claim (indeed, I think perhaps the key claim in FMF), is that a wide range of economic liberties-such as full freedom of contract,

\footnotetext{
1 Tomasi's distinction between self-respect and self-authorship seems-to me-to be rather fluid and ill defined, and the two are used somewhat interchangeably at various points in FMF (see for example Tomasi 2012, pp. 81-84). Whilst Tomasi clearly intends his account of self-authorship to supplant Rawls's account of the two moral powers, my feeling is that Tomasi-fairly-takes both concepts to be heavily concerned with the idea that citizens' are genuinely self-directed, and that threats to this selfdirection threaten both the sense of self-authorship and self-respect.
} 
ownership of the means of the production and rights to the transfer and disbursement of property-plausibly support citizens in feeling a sense of selfrespect and self-authorship, in ways that are similar to those provided by the more restrictive property rights Rawls advocates (Tomasi 2012, p. 76). As such, the justification for treating them differently looks weak.

I think the problem that Tomasi raises here is a real one. It seems to me that the standard Rawls offers of 'providing support for self-respect/self-authorship' is both too weak, and too vague to be of much use to us in identifying the basic libertiesespecially when we consider how important such a task would be within the Rawlsian schema. ${ }^{2}$ Nonetheless, I think Tomasi ends up drawing rather more from this observation than he is able to sustain. Or rather, I think that a Rawlsian can offer some grounds for saying that the restricted ownership of private property (as embodied in a property-owning democracy) can support citizens' self-respect in ways which justify it being treated as a basic liberty-whilst refusing to treat Tomasi's broader set of economic liberties as similarly basic.

Tomasi argues that 'Rawls seems unable to imagine how the self-respect of people could be tied directly to the exercise of general economic liberty.' (Tomasi 2012, p. 43) But this is surely too strong. Nowhere does Rawls say that the general exercise of the rights of ownership, negotiation and transfer cannot support people's development of their self-respect, or their sense of self-authorship. ${ }^{3}$ Rather, Rawls's claim is that the restricted right to private property is necessary to allow 'a sufficient material basis for a sense of personal independence and self-respect...' (Rawls 2001, p. 114 emphasis mine). ${ }^{4}$ This is a very different claim to the one that Tomasi considers. And contra Tomasi, a Rawlsian could quite easily say that the kinds of economic rights which are necessary for the adequate or sufficient development of one's self-respect or self-authorship may well be very different to those which support the development of these senses in general. This is to say Rawls could accept that all economic liberties offer support for self-respect and self-authorship, whilst not treating all economic liberties as equal. This, it appears, is what he does. ${ }^{5}$

Of course, this move itself requires a number of justifications that Rawls does not provide-and this is why this area is such fertile ground for both Tomasi, and left-

\footnotetext{
2 Indeed, this problem is one with quite a history amongst theorists to the left of Rawls, who are also keen to exploit his (intentional) parsimony regarding the basic liberties in order to read Rawls in their preferred (typically more egalitarian) way. As such, it seems fitting that we afford equality of opportunity to critics on the right to do the same. See for example Doppelt (2009), Moriarty (2009), Hsieh (2008), Arnold (2012).

3 Indeed it is surely this kind of concern that underlies the role of private (non-productive) property as a basis for self-respect.

4 See also 'These wider conceptions of property are not used because they are not necessary for the adequate development and full exercise of the moral powers, and so are not an essential social basis of self-respect.' (Rawls 2001, p. 114, emphasis mine). I accept that Rawls's claim regarding the full exercise of the moral powers here also gives support to Tomasi's reading.

5 It is here that a defender of FMF might want to draw a sharper distinction between the idea of selfrespect, and self-authorship, such that the latter should be understood more squarely as the development of the moral powers Rawls is concerned with. This move seems fair (and Tomasi arguably makes it: Tomasi 2012, pp. 40-41). However, given that Rawls explicitly names self-respect as one ground for identifying the basic liberties, the shift of the argumentative burden onto self-authorship only appears to leave this unaddressed.
} 
liberals. However, plausible justifications could be provided. In the first instance we ought to note that Rawls's account of self-respect lends itself more naturally to a more sufficientarian reading of the kind needed to underlie the claims above. ${ }^{6}$ This is to say that Rawls_-unlike Tomasi (2012, p. 82) — does not appear to treat self-respect (at least) as something which should be maximised, rather than simply secured at some acceptable level. Rawls's account of self-respect emphasises its importance in ensuring that each citizen feels suitably motivated to enter into cooperation with others and pursue their chosen plan of life with confidence and a lively sense of its worth (Rawls 1999, p. 386). It is towards this goal that much of justice as fairness is arguably oriented. But it seems quite plausible that the sense of self-respect that citizens need to pursue such plans could be relatively modest. This is to say that once Rawlsian citizens have the confident sense that their plans are worth pursuing, and that they are up to the task, it is not clear that there is any great pressure to make them feel ever increasingly certain that their plans are worth pursuing, and that they are increasingly certain of being up to the task. The additional economic liberties which Tomasi favours then, might simply appear less pressing from the Rawlsian perspective.

An advocate of market democracy might respond (fairly) at this point, that the mere fact that these economic liberties are not strictly necessary for the development of self-respect is a rather weak reason to exclude them from the class of basic liberties. After all, if we are to value self-direction in the way that both Rawls and Tomasi want us to, then there would seem to be a more general presumption in favour of those liberties which helped to secure it. However, I think there are other reasons that a Rawlsian may be sceptical of affording all such liberties the status of basic liberties. The first of these relates simply to the kind of project Rawls was engaged in. In Rawls's specification of the basic liberties in Justice as Fairness, he takes care to note that the kinds of economic liberties that Tomasi advocates for may still be justified by particular historical and social circumstances (Rawls 2001, p. 114). It seems likely that much of Rawls's desire to limit the class of basic liberties stems from his hopes that justice as fairness can be accepted as a reasonable starting point for parties with differing normative convictions. The justification for excluding Tomasi's favoured economic liberties then, may well be rather more methodological than normative.

Whilst I think there is some truth in this claim, I believe there are more substantive (and more interesting) reasons for Rawlsians to reject Tomasi's argument that the wider economic liberties he proposes ought to be treated as basic in the name of self-respect. In particular, we should also recognise that the wider economic liberties that Tomasi proposes appear to pose ancillary risks to some citizens' self-respect that are not so present or pronounced with regards to the more restricted property rights that Rawls proposes. Thus even if both sets of rights offer similar support for citizens' senses of self-respect/self-authorship, we might distinguish between them if they caused other harms to (perhaps other) citizens' self-respect in different ways.

\footnotetext{
${ }^{6}$ See for example Rawls (functional) claim that citizens require the social bases of self-respect which are necessary for them 'to be able to realize their higher-order interests and advance their ends with zest and self-confidence.' (Rawls 2001, p. 60).
} 
On this score, Rawls is clear that he expects citizens' self-respect to be supported by, at least, the fair values of political liberties (Rawls 1993, p. 318), fair equality of opportunity (Zink 2011, p. 337) and also the sense of fraternity which comes when citizens agree to refrain from exploiting their natural and social circumstances to their own private benefit (Rawls 1999, p. 156). In my view at least (though defenders of market democracy might disagree) it seems likely that the substantially greater inequality which would accompany Tomasi's wider economic liberties would jeopardise the ability of the basic structure to secure these other forms of support for citizens' self-respect (see Penny 2013). And if so, then even if such liberties did offer one kind of support to the sense of independence and self-respect that some individuals experienced, Rawlsians might have further reasons for not treating these wider economic liberties as basic - if they threatened other, or more important sources of support for self-respect more generally.

These observations clearly do not offer a full or adequate reconstruction of the Rawlsian justification behind the constitution of the basic liberties. But I believe they serve to show that the widening of these liberties in the name of self-respect is not quite as straightforward as Tomasi supposes. I will now turn to address Tomasi's account of self-respect, and the role it plays in FMF more directly.

\section{Thick Economic Liberties and Self-Authorship}

We might understand Tomasi's arguments thus far as a 'positive' claim about the wider economic liberties he supports. This is to say that Tomasi wants to offer us positive reasons for supposing that wider economic liberties can support self-respect effectively (and should be treated as basic liberties in this regard). But Tomasi also makes a number of interesting 'negative' claims about the effects that might stem from excluding these wider forms of liberties from the class of basic liberties. In other words, claims as to why it might be harmful to citizens' self-respect if we were to fail to treat these wider economic liberties as basic.

The most forceful of these claims is that the failure to protect these kinds of liberties acts as a kind of paternalistic or disrespectful harm to citizens' self-respect more widely. Tomasi asks us:

... how can individuals have self-respect if their fellow citizens deny them the right to decide for themselves how many hours they will work each week and under what precise terms and conditions? How can they think of themselves as esteemed by their fellow citizens if those citizens call on the coercive force of the law to impede them in deciding for themselves how much (or little) to save for retirement, the minimum wage they may find acceptable for various forms of work, or to dictate the parameters of the medical care that will be available to them? (Tomasi 2012, pp. 83-84)

Tomasi is quite correct to identify these kinds of social esteem and recognition as being vitally important to Rawls's understanding of how citizens' develop selfrespect. But despite the rhetorical force of these claims, I am not persuaded that these kinds of limitation of citizens' agency necessarily, or on balance, represent 
harms for citizens' self-respect. Let us take for example the question of minimum wage laws. On Tomasi's account, these pose a harm to self-respect that runs something like this: Some mass of citizens, or associations (most likely labourunions) cooperate to apply pressure to a political body, such that it moves to legislate a certain minimum wage at which citizens and employers may contract to buy and sell labour. ${ }^{7}$ But these laws curtail the ability of individuals to negotiate contracts freely, and enter into employment relationships of their own choosing. This, Tomasi claims, truncates these individuals' ability to exercise their powers of self-authorship, and be fully self-directed. And further, it represents a form of contempt or disrespect on the part of their fellow citizens that they do not trust one another to exercise these powers responsibly (Tomasi 2012, pp. 81-84). Both of these effects have plausible (negative) implications for citizens' self-respect.

I do not think there is anything mechanically at fault with Tomasi's reasoning here, and I can quite believe that some individuals might view or experience such workplace legislation as disrespectful and stifling. However, it seems to me that there is an equally (if not more) compelling way of re-describing this process which points in quite the other direction regarding citizens' self-respect.

For starters, we should note that once these kinds of liberties - of contract and workplace rights - are shifted out of the constitutional level of Rawls's schema and into the legislative sphere, they take on a more, rather than less, deliberative character. As such, Tomasi's characterisation of citizens' 'calling on the coercive force of the law to impede one another' seems rather uncharitable (Tomasi 2012, p. 84). Instead, any such laws will be the product of a critical mass of citizens engaging one another in a process of political deliberation and exercising their political liberties in order to pursue their preferred legislative outcomes-a process Tomasi (elsewhere) lauds as a positive aspect of market democracy (Tomasi 2012, p. 90).

The formation of these laws then, not only appears to be born of the kinds of political engagement which are important for citizens' self-respect-but further, only appears to infringe on people's sense of self-authorship only in the way that any piece of regulation does so. Any law worth passing will limit what some individuals are able to choose, or contract to do. But a great deal of these are surely very mundane and unavoidable—such as regulations on noise pollution, or the location of public utilities. Tomasi may well feel that such regulations are problematic too, but in this case then it seems to me that citizens must either accept complete political paralysis, or concede that some minimal loss of self-authorship is simply 'baked into' the idea of a community which resolved questions of competing interests through democratic processes. ${ }^{8}$ One cannot have the self-authorship

\footnotetext{
${ }^{7}$ In the US and the UK, this is typically a minimum wage applying to all or most jobs-but it is worth noting that in other areas, notably Scandinavia, different minimum wages are negotiated for different sectors of the economy (see Grimshaw 2013 for a summary of different minumum wage models).

8 Tomasi would surely agree with Rawls that citizens exercise of their political rights and deliberative powers is itself a basis for their feeling self-respect. But note that these kinds of benefits only occur in a context where citizens are able to 'call on the coercive force of the law to impede one another'. If political activity were merely window dressing, it is not clear how it could operate as the important basis for selfrespect that Rawls (at least) expects it to.
} 
benefits of political deliberation if the deliberative bodies in question are unable to act upon their decisions.

Of course, market democrats will be itching to reply that these (or many) forms of regulation are not unavoidable, and that some legislation could surely impinge severely on our sense of self-authorship despite being democratic in character. This, however, is not my claim. I certainly agree that were a majority of our peers to freely vote to, say, impose a uniform dress code on society, this would certainly seem to curtail our self-authorship and self-respect in a problematic way. The claim I want to make instead though is that some residual degree of regulation is inevitable in a deliberative community, and this fact, when coupled with some (hitherto undefined) standard of public justifiability may serve to render such restrictions on self-authorship as self-respect compatible. I do not have space to explore this point fully, but it seems quite plausible to me that some forms of restriction on trade need not excessively harm our sense of self-authorship. I am not convinced that, for example, bans on pyramid selling schemes or loan-sharking need be understood as being disrespectful, or stifling on the part of our peers. In fact, quite the contrary seems true to me, such that the best justification for these kinds of restrictions will rest in part upon our respect for the plans of others, which we do not want to see curtailed or limited by genuine mistakes on their part, or bad faith on the part of others.

More significantly though, I am not convinced that Tomasi properly engages with the fact that questions over issues such as employment rights involve a balance of harms-including towards self-respect, and self-authorship. Thus whilst laws which set the minimum wage at $\$ 5$ might restrict the ability of one individual who desires to sell their labour for $\$ 4$, such laws also-by design-might allow another individual who wishes to sell their labour at no less than \$5 (but due to market forces, was previously unable to do so) to form such a contract. This is to say that minimum wage laws plausibly enable just as many individuals to sell their labour at a chosen price, as they prevent from doing so. It is not clear to me why Tomasi thinks that latter gain in self-authorship (such that an individual can sell their labour at a price they choose, less restricted by market forces) would be inherently less important than the loss of self-respect of the individual who cannot sell their labour at the price they choose, thanks to minimum wage legislation. ${ }^{9}$

The same argument seems to apply, mutatis mutandis, with regards to other labour rights such as workplace safety laws, or parental leave legislation. ${ }^{10}$ As such, whilst a society with robust minimum wage laws, workplace regulation and employment rights might well prevent many individuals from selling their labour in ways that the state does not permit, it also enables many others to sell their labour in

\footnotetext{
9 There may of course be ancillary economic reasons (such as concerns about efficiency or unemployment) for such avoiding minimum wages of this kind. My focus here is simply on the claim that such policies are necessarily stifling of self-authorship.

10 Take for example the issue of compulsory union membership. On the one hand, 'right to work' laws allow anti-union workers greater potential for self-authorship. But on the other hand, they also effectively preclude other workers from forming a reasonably powerful trade union. We need not take sides here to recognise there is no policy in such cases that does not affect some individuals' potential for selfauthorship.
} 
ways that the market would not permit, absent state intervention. Tomasi is surely correct that some individuals will have their self-authorship truncated as a resultbut many others, and particularly those most at risk of exploitation, will have their ability to self-author massively increased by these kinds of interventions. This is true both in the sense that such they are able to negotiate with the bulwark of such legislation behind them, and in the sense that they can act in accordance with others to author this legislative framework itself.

As such, it seems to be at least contestable that some restrictions on freedom of contract might be compatible with the development of citizens' self-respect-either because these restrictions are (in terms of being unavoidable, and/or justifiable) not problematic in themselves, or because they contribute to a much larger degree of self-authorship overall. Tomasi's account of self-respect, I think, does not offer us the tools which allow him to draw the dividing lines that he does.

\section{Self-Respect as the Central Cause of a Successful Life}

A defender of market democracy is unlikely to accept much of the above-on economic grounds at the very least. And certainly, the strength of both sets of claims about, say, minimum wage laws will depend heavily on just how stifling or emancipatory such legislation really is in practice. I have neither the space nor expertise to engage in such analysis here, though I would note that for all the classical economic literature on the 'job-killing' nature of minimum wage laws, the European experience has shown that such legislation can be compatible with quite moderate levels of unemployment. ${ }^{11}$ But aside from this Tomasi has one final challenge for left-liberals who are notionally committed to the idea that the socioeconomic structure of society ought to act so as to support citizens' self-respect. This argument is interesting because, I believe, Tomasi sees it as providing the strongest support for his claim that market democracy is a superior guarantor of citizens' self-respect, whereas for my part, it appears to be the weakest and most problematic of the claims that Tomasi presents.

Tomasi asks us to consider what it is that makes our lives, and particularly our labour, feel worthwhile. What it is, in other words, that allows us to look at ourselves in the mirror with a sense of pride or respect. In response, Tomasi offers a fairly distinctive account of the conditions under which individuals might properly, or really, respect themselves. On Tomasi's account our having self-respect is dependent, at least in part, on our having a sense that we ourselves are the 'central causes' of the life we are leading (Tomasi 2012, p. 83). This is to say then that what matters in terms of our self-respect is not just the situation we find ourselves in, but the extent to which this situation is of our own making.

By way of illustration, Tomasi draws approvingly upon claims made by Charles Murray who argues variously that welfare and social systems which seek to insulate individuals from economic risk 'takes the trouble out of life' and 'drains too much

\footnotetext{
11 For example, the introduction of the British national minimum wage appears to have had little or no effect on employment (Metcalf 2008).
} 
of the life from life.' (Murray 2006, p. 82; Tomasi 2012, p. 80). For both Murray and Tomasi, it appears that individuals' achievements, their success in pursuing their plans, and upholding their commitments cannot add (much) to their sense of self-respect if they themselves are not the central cause of these outcomes. Thus Tomasi sees fit to argue that '... a person's self-respect is diminished if one is not (and so cannot think of oneself as) the central cause of the life one is leading. Having others secure them with "material means" could not provide liberal citizens with that form of self-respect.' (Tomasi 2012, p. 83)

The implication that Tomasi draws from this is that the programs of wealth redistribution, public services and, perhaps, equalities legislation which are favoured by left-liberals are incompatible with ensuring that citizens derive a sense of self-respect from the achievements that these goods (may) facilitate. In accepting such support, citizens lose the sense that they are the causes of their lives-and in so doing, they lose the sense of value in these pursuits which underlies their selfrespect.

Tomasi apparently views this as something of a knock-down argument against the left-liberal position. But I am far from convinced. In the first instance I find Murray's claims to be, frankly, a little bizarre. I simply do not think that many Europeans would recognise any truth in the claim that: 'By insulating people from economic risks, the European model denies ordinary citizens opportunities to feel the special sense that they have done something genuinely important with their lives.' (Tomasi 2012, p. 80). Tomasi makes a great deal of play of the observation that under conditions of rising affluence, citizens apparently tend towards favouring greater economic liberty, and care less and less for public services, workplace rights, collective bargaining and the like (Tomasi 2012, p. 61). I strongly doubt that this is straightforwardly the case, even in the cases that Tomasi cites, ${ }^{12}$ but even if it were, then the actually-existing support for the European model (inasmuch as such a model exists) would challenge this thesis. ${ }^{13}$

Furthermore, there seem to be a great many examples in which one's being a 'central cause' of their life does not appear be a necessary condition of one's having self-respect in the way that Tomasi's claims. Consider a disabled individual, for example, who is able to lead an active life, to engage in employment and participate fully in their local community, but only because the state mandates (or provides resources) such that all local buildings are wheelchair accessible. Would this individual really feel that their self-respect was diminished as a result? That their achievements, and plans were not really their own? Or that-worse-too much of the 'trouble' had been taken out of life? Would they really respect themselves more

\footnotetext{
${ }^{12}$ My understanding is that even in the US, support for (notionally) left-liberal parties is still strongly correlated with income (see for example Gelman 2009). And, further, it seems to be a rather large leap of faith to attribute the shifts in public attitudes towards the welfare state in the West over the last 30 years to this kind of deep psychological preference for liberty, rather than the manifold other causal candidates (at the very least the role of globalisation, the increased political power of capital, and the inability of many states to respond adequately to many aspects of the modern and post-modern order).

13 See Svallfors (2012) for a very thorough analysis of European attitudes towards the welfare state, and an illustrative comparison with attitudes in the US.
} 
if they were limited to engaging in public life only when they could do so on their own terms ? $^{14}$ This seems dubious at best.

Proponents of market democracy might wish to make exceptions for those with disabilities-(though I am not sure how they could do so without conceding the point in question). But just in case, let us also consider another example. Suppose that an individual has spent much of their youth caring for a sick relative, and as such they have developed a very specific and limited set of skills, such that they make an excellent carer for those in need. They are, say, extremely empathetic, patient, level headed and reliable. And, let us suppose also that they identified very strongly indeed with these skills and their status as a carer. And, suppose also that hitherto, their ability to care has been enabled by a carers allowance from the state, such that they did not have to seek income from elsewhere. Are we really to say that this individual should relish the liberating idea of this grant being withdrawn such that they either have to give up on their caring role, or secure their own sources of funding for it (perhaps through charity, or worse, asking for payment from those they care for)? This too seems highly questionable.

Here then we can see a substantial difference between Rawls and Tomasi with regards to what makes peoples plans feel worthwhile, and what affords them selfrespect. For Rawls it is the planning, revision and pursuit of plans per se that has value. Thus individuals treat sources of social support as foundations upon which to build their plans. I find Rawls's account here much more desirable than Tomasi's, for at least three reasons. Firstly, Rawls simply seems to be correct when he says that individuals can, and ought to, revise their plans in accordance with their changing social and economic positions. For Rawls then, it is not that individuals form a set of desires and commitments, and then having had these goals facilitated by sources of social support, are unable to glean any sense of purpose from pursuing them. Rather, increased social support affords citizens the ability to pursue more complex and rewarding commitments and pursuits, and such citizens can moderate and develop their plans in kind. Liberating individuals from want and need does not, on Rawls's account, rob their lives of meaning, but rather opens up new areas in which they might become self-authors. In a position of relative economic security, Rawls believes, individuals are more meaningfully able to manifest their individuality and agency, in ways people typically cannot when they are wrestling with the drudgery of subsistence.

Secondly, Tomasi's argument regarding one's being a central cause appears to focus far too heavily on the 'agent-centred' 15 aspects of self-respect. Tomasi is surely correct to say that individuals ought to have some stake in their achievements - and some sense that they brought them about. Lottery wins and accidents of fortune, for example, do not appear to be good grounds for individuals to feel a sense of self-respect. However, it is not clear that we need to go as far as Tomasi-towards full 'central causality' in response. It is surely the case that individuals' self-respect can be influenced by both their own actions and

\footnotetext{
14 This is supposing, of course, that we say with confidence what 'on their own terms' would mean. See Fishkin (2014), for recent discussion of this challenge.

15 See Zink (2011), for an interesting discussion of these aspects.
} 
motivations, and also supported by, for example, social support in the forms of resources, opportunities and training-as well as general social esteem and encouragement. This is something that Rawls recognises explicitly (Rawls 1999, p. 387), and this balance of 'agent-centred' and social sources of support for selfrespect seems, to me, far more plausible than the account Tomasi offers.

Finally, a vital aspect of Rawls's account of self-respect is the recognitional role played by sources of social support which enable all citizens to pursue meaningful plans for their lives. Thus, for example, distributions of wealth, or public services which are intended to bring about equality of opportunity also have, on Rawls's view, a quite discreet and quite powerful recognitional effect-publicly establishing the equal standing of each citizen, and publicly affirming their status as free and equal persons. This is an aspect of Rawls's account of self-respect which is often overlooked, but it is, I think, an important one. It is not clear to me that the market democracy of the kind that Tomasi describes can offer this kind of recognitional affirmation for self-respect to the same degree.

\section{Self-Delusion and the Greater Wealth Thesis}

These points indicate that the gap between Tomasi's and Rawls's accounts of selfrespect may be greater than they appeared at first sight, and further, that there may reasons as to why Rawlsians may not find Tomasi's account of self-respect very desirable. And, as I noted, I think this may limit the force of Tomasi's claims on the Rawlsian position. However, a larger problem still looms, and I will conclude by setting this out. This claim is essentially that not only is Tomasi's account of selfrespect not persuasive, but there is a major tension between this account, and the wider market democratic project which Tomasi is advocating.

To bring this out, let us recapitulate what, I think, is the major, and most challenging point in favour of market democracy. This is what Tomasi terms the 'greater wealth thesis' (Tomasi 2012, p. 187). In its most basic terms, this is essentially the claim that adopting the wider class of economic liberties as basic liberties would, amongst other things, lead to a more laissez-faire economic system that would in turn drastically increase the rate at which the economy in question grew. Citizens would, in effect, agree to sacrifice many of their social and employment rights in return for a more open and dynamic economy, which (over time) afforded them a far greater quantity of wealth and income than they could receive under a more 'sluggish' left-liberal model. Tomasi believes that this greater share of wealth means that this kind of distributive model fits well with the ethos of the difference principle — maximising the position of those least advantaged — and further that it can play an important role in securing de facto rights and opportunities for individuals, by releasing them from economic hardship or vulnerability (Tomasi 2012, pp. 188-191).

I do not wish to comment on the plausibility of this claim, other than to register my concerns about its optimism. Let us suppose though that things did pan out in the way that Tomasi hopes - such that a citizenry did adopt the market democratic model, and after some period of time-let us say 50 years, found themselves in a position of quite fantastic social wealth of the kind that Tomasi describes (Tomasi 
2012, pp. 234-235). And, suppose that as a result, even those who were least advantaged really could enjoy a very substantial quality of life, and be extremely discerning about the conditions under which they chose to labour and toil. ${ }^{16}$

The question I want to pose here is whether this outcome is at all reconcilable with the account of self-respect that Tomasi directed against the social provisions supported by left liberals? Or more bluntly, if it really is the case that insulating individuals from economic risk 'takes the trouble out of life' and 'drains too much of the life from life', then what on earth is the point of pursuing this by means of economic growth, and social enrichment in the first place? Why is it that we would not also have to say, a la Murray, that:

By insulating people from economic risks, the [market democratic] model denies ordinary citizens opportunities to feel the special sense that they have done something genuinely important with their lives?

If Tomasi cannot give us a compelling answer to this question, it strikes me as being a major problem for his account more widely. To renege on the value of the greater wealth thesis would be unthinkable. But if Tomasi is instead to water down the importance of self-respect as a justification, or to move his account of selfrespect closer to Rawls's, then he also loses much of the justification for rejecting the left-liberal position in the first place.

The problem is that I simply do not see how Tomasi can reconcile these two positions. I cannot see, that is, how economic and social security born of wealth redistribution or public services can be said to harm citizens' self-respect, whilst the same economic and social security born of the general productive capacity of the economy would not. The obvious move for a market democrat is to fall back on the claim that individuals need to feel themselves to be the central causes of their position of economic security, and as such, money earned in a market democratic economy would offer them a greater sense of self-authorship, and self-respect than money received in welfare benefits or the like, in a left-liberal economy. But this is surely a fiction on the part of the individual. This individual is not a 'central cause' of the overall economic capacity of the market democratic society. This is something which has come about quite independently of, and probably prior to, their efforts. As such they are not a central cause of their economic security, even if they are the cause of their economic income.

To illustrate, compare a worker who worked $20 \mathrm{~h}$ a week in the 1950, and whom, as a result, could barely feed and accommodate themselves and their familylet alone deal with any unexpected shocks such as illness or injury. Now consider the same individual doing exactly the same work today. It seems likely that-given technological advances, changes in the costs of living and the overall growth of the economy, this individual could live quite an economically secure (though by no means decadent) lifestyle on the same $20 \mathrm{~h}$ of work a week. But it would seem very odd indeed for this individual to say they were the 'central cause' of their economic

\footnotetext{
${ }^{16}$ We are also assuming here that the share of wealth and income which accrues to those worst off remains (at least) constant. It is perhaps worth noting that has not, at least in the US, been the case in recent history (see Tcherneva 2014). I thank a reviewer for this point.
} 
security in the year 2013, any more than they were the central cause of their economic insecurity in 1950. They certainly have some responsibility for their economic situation in both periods, but it would seem to be rather grandiose for them to ignore the more general economic and technological development which had led to their comfort in the present day, and attribute this security solely to their own efforts, such that they were a 'central cause' of such conditions.

But if it is the case that citizens cannot credibly view themselves as the central causes of their economic security in times of great affluence, then Tomasi rather risks being hoist by his own (or perhaps Murray's) petard. It is not clear how, without deluding themselves about the degree to which they are causally responsible for their position, citizens in an affluent market democratic utopia could maintain a sense of self-respect when economic security is so readily attainable, and so minimally a product of their agency. At the very least, the benefits of this model in terms of self-respect seem far less clear. Either the independent economic structure can support our plans without compromising our self-respect, or it cannot. And if it can, then I do not see why well designed welfare-states and redistributive policies cannot do the same. ${ }^{17}$

As I noted earlier, given the important role Tomasi affords this conception of self-respect in both attacking the liberal-left position, and defending market democracy, this would appear to be a rather significant problem indeed. The problem for Tomasi, I feel, is that dining at the table of left-liberalism means swallowing something of a poison pill along the way. Namely, that in accepting the left-liberal idea that economic distribution ought to be-at some minimal levelsocially directed, the idea that there is a natural economic order, or that individuals have anything near full responsibility for their economic circumstances falls away too. I for one am comfortable with this as a premise-but I am not sure that this kind of concession can be made to function alongside the kind of treatment Tomasi wants to offer of self-respect.

Nonetheless, there remains much to admire about Free Market Fairness, not least its ambition. Tomasi's account of market democracy raises many important questions for left-liberals-especially as we move further away from conditions of moderate scarcity. And perhaps the most important contribution Tomasi makes is not only identifying the grounds above as the proper site for debates about justice, but also in arguing that such a perspective lies dormant in much classical liberal, and libertarian thought (Tomasi 2012, pp. 124-142). It may not be prudent for leftliberals to board Tomasi's 'icebreaker' themselves (Tomasi 2012, p. 102), but that is no reason not to salute him as he sails by.

Open Access This article is distributed under the terms of the Creative Commons Attribution 4.0 International License (http://creativecommons.org/licenses/by/4.0/), which permits unrestricted use, distribution, and reproduction in any medium, provided you give appropriate credit to the original author(s) and the source, provide a link to the Creative Commons license, and indicate if changes were made.

\footnotetext{
17 For example, I am happy to accept that a state which cancelled all education programs and allowed individuals to draw upon a (self-titled) 'indolence benefit' whenever they faced difficulty in their lives might well fall afoul of Tomasi's and Murray's concerns. This of course is some distance from the reality of most successful welfare states.
} 


\section{References}

Arnold, Samuel. 2012. The difference principle at work. Journal of Political Philosophy 20: 94-118.

Doppelt, Gerald. 2009. The place of self-respect in a theory of justice. Inquiry 52: 127-154.

Fishkin, Joseph. 2014. Bottlenecks: A new theory of equal opportunity. Oxford: Oxford University Press.

Gelman, Andrew. 2009. Red state, blue state, rich state, poor state: Why Americans vote the way they do (expanded edition). Princeton: Princeton University Press.

Grimshaw, Damian. 2013. Minimum wages, pay equity, and comparative industrial relations. London: Routledge.

Hsieh, Nien-he. 2008. Survey article: Justice in production. Journal of Political Philosophy 16: 72-100.

Metcalf, David. 2008. Why has the British national minimum wage had little or no impact on employment? Journal of Industrial Relations 50: 489-512.

Moriarty, Jeffrey. 2009. Rawls, self-respect, and the opportunity for meaningful work. Social Theory and Practice 35: 441-459.

Murray, Charles. 2006. In our hands: A plan to replace the welfare state. Washington: AEI Press.

Penny, Richard. 2013. Incentives, inequality and self-respect. Res Publica 19: 335-351.

Rawls, John. 1993. Political liberalism. New York: Columbia University Press.

Rawls, John. 1999. A theory of justice, revised edition. Cambridge, MA: Belknap Press of Harvard University Press.

Rawls, John. 2001. Justice as fairness: A restatement. Cambridge, MA: Harvard University Press.

Svallfors, Stefan. 2012. Contested welfare states: Welfare attitudes in Europe and beyond. Stanford: Stanford University Press.

Tcherneva, Pavlina. 2014. Reorienting fiscal policy: A bottom-up approach. Journal of Post Keynesian Economics 37: 43-66.

Tomasi, John. 2012. Free market fairness. Princeton, NJ: Princeton University Press.

Zink, James. 2011. Reconsidering the role of self-respect in Rawls's A Theory of Justice. The Journal of Politics 73: 331-344. 